\title{
The Beneficial Impact of Antidepressant Drugs on Prenatal Stress- Evoked Malfunction of the Insulin-Like Growth Factor-1 (IGF-1) Protein Family in the Olfactory Bulbs of Adult Rats
}

\author{
Ewa Trojan ${ }^{1} \cdot$ Katarzyna Głombik $^{1} \cdot$ Joanna Ślusarczyk $^{1} \cdot$ Bogusława Budziszewska $^{1}$ • \\ Marta Kubera $^{1}$ - Adam Roman ${ }^{2}$. Władysław Lasoń ${ }^{1} \cdot$ Agnieszka Basta-Kaim $^{1}$
}

Received: 4 September 2015/Revised: 6 November 2015/Accepted: 7 November 2015/Published online: 26 November 2015

(C) The Author(s) 2015. This article is published with open access at Springerlink.com

\begin{abstract}
Insulin-like growth factor-1 (IGF-1) promotes the growth, differentiation, and survival of both neurons and glial cells, and it is believed to exert antidepressant-like activity. Thus, disturbances in the IGF-1 system could be responsible for the course of depression. To date, there have been no papers showing the impact of chronic antidepressant treatment on the IGF-1 network in the olfactory bulb $(\mathrm{OB})$ in an animal model of depression. Prenatal stress was used as model of depression. Twenty-four 3-month-old male offspring of control and stressed mothers were subjected to behavioral testing (forced swim test). The mRNA expression of IGF-1 and IGF-1 receptor (IGF-1R) and the protein level of IGF-1 and its phosphorylation, as well as the concentrations of IGF-binding proteins (IGFBP-2, -4, -3, and -6), were measured in OBs before and after chronic imipramine, fluoxetine, or tianeptine administration. Adult rats exposed prenatally to stressful stimuli displayed not only depressionlike behavior but also decreased IGF-1 expression, dysregulation in the IGFBP network, and diminished mRNA expression, as well as IGF-1R phosphorylation, in the OB. The administration of antidepressants normalized most of the changes in the IGF-1 system of the OB evoked by prenatal stress. These results suggested a beneficial effect of chronic antidepressant drug treatment in the alleviation of IGF-1 family malfunction in OBs in an animal model of depression.
\end{abstract}

Agnieszka Basta-Kaim

basta@if-pan.krakow.pl

1 Department of Experimental Neuroendocrinology, Institute of Pharmacology, Polish Academy of Sciences, 12 Smętna St, 31-343 Cracow, Poland

2 Department of Brain Biochemistry, Institute of Pharmacology, Polish Academy of Sciences, 12 Smętna St, 31-343 Cracow, Poland
Keywords Antidepressant drugs - Prenatal stress · Olfactory bulbs · Insulin-like-growth factor 1 (IGF-1) family

$\begin{array}{ll}\text { Abbreviations } \\ \text { ANOVA } & \text { Analysis of variance } \\ \text { BDNF } & \text { Brain-derived neurotrophic factor } \\ \text { CNS } & \text { Central nervous system } \\ \text { ELISA } & \text { Enzyme-linked immunosorbent assay } \\ \text { Flu } & \text { Fluoxetine } \\ \text { IGF-1 } & \text { Insulin-like growth factor-1 } \\ \text { IGF-1R } & \text { Insulin-like growth factor-1 receptor } \\ \text { IGFBP } & \text { Insulin-like growth factor binding protein } \\ \text { Imi } & \text { Imipramine } \\ \text { OBs } & \text { Olfactory bulbs } \\ \text { OVS } & \text { Sodium orthovanadate } \\ \text { PMSF } & \text { Phenylmethanesulfonyl fluoride } \\ \text { PVDF } & \text { Polyvinylidene fluoride } \\ \text { SEM } & \text { Standard error of the mean } \\ \text { SVZ } & \text { Subventricular zone } \\ \text { TBS } & \text { Tris-buffered saline } \\ \text { Tia } & \text { Tianeptine } \\ \text { TMB } & 3,3^{\prime}, 5,5^{\prime}-\text { Tetramethylbenzidine } \\ \text { Veh } & \text { Vehicle }\end{array}$

\section{Introduction}

Apart from changes in neurotransmitters and the dysregulation of the immune and endocrine systems, studies have postulated that impairments in synaptic plasticity and neurogenesis also play important roles in the development of depression (Bredt et al. 2015). Furthermore, data have shown that depression might result from alterations in the 
neurotrophic factors expression in the central nervous system (CNS) (Branchi et al. 2004). Interestingly, in addition to brain-derived neurotrophic factor (BDNF), insulin-like growth factor-1 (IGF-1) has recently attracted a significant amount of attention.

IGF-1 is a small peptide $(7.5 \mathrm{kDa})$ that is produced not only in the periphery but also in various parts of the CNS, such as the cerebellum, hypothalamus, striatum, cerebral cortex, hippocampus, and olfactory bulbs (OB) (Bondy 1991; de Pablo and de la Rosa 1995). In the brain, IGF-1 has combined effects on neural cell signaling and neurotrophic responses (Hoshaw et al. 2008). Moreover, it plays a crucial role in brain development, mainly through control of cell growth, differentiation, maturation, and survival. Data have reported that IGF-1 exerts biological functions particularly via the IGF-1 receptor (IGF-1R), which is a transmembrane heterotetramer consisting of two extracellular $\alpha$ subunits containing the IGF-binding site and two intracellular $\beta$ subunits that exhibit tyrosine kinase activity (Annuziata et al. 2011). The brain's IGF-1 bioactivity and bioavailability are controlled by the IGF-binding protein (IGFBP) family. Furthermore, it has been suggested that brain IGFBPs participate not only in IGF-1 regulation but also in many brain processes, e.g., IGF-1-dependent neurogenesis, gliogenesis (Ajo et al. 2003), myelination, and synapse formation (Bunn et al. 2005). Data demonstrate that the concentrations of IGFBPs are area specific in the CNS (Ocrant 1991, 1993; Han et al. 1996). Among the six proteins, IGFBP-2 is believed to be the principal binding protein in the brain. Great importance is also ascribed to IGFBP-4, the only 'classic' binding protein, which does not exert any actions independently of IGF-1 (Mazerbourg et al. 2004; Ning et al. 2008). Some data have suggested that an appropriate balance between IGFBP-2 and IGFBP-4 is crucial for maintaining proper IGF-1 concentrations and biological activities.

IGF-1 expression in the brain is high during early organogenesis, and it diminishes after delivery (Ashpole et al. 2015). In adults, IGF-1 expression remains elevated only in areas with large projection neurons, such as the cerebellum, hippocampus, and cortex (Russo et al. 2005). Interestingly, the OBs are the regions where high levels of this protein and its receptor exist in both postnatal and adult brains. It has been postulated that high IGF-1 concentrations in this structure constitute a brain collateral "reservoir" for other brain areas, namely the hippocampus and frontal cortex (de Pablo and de la Rosa 1995; Freitas et al. 2013). Moreover, elevated IGF-1 concentrations are critical for embryonic and adult neurogenesis in the OB, especially in the processes of neuronal migration and positioning (Hurtado-Chong et al. 2009). In contrast, the experimental bulbectomy, thus lowering the IGF-1 level, has been established as a rodent model of depression.
This procedure induces alterations in behavior, endocrine, immune, and neurotransmitter systems commonly observed in depressed patients (Kelly et al. 1997; Song and Leonard 2005). These data led to the suggestion that IGF-1 might act as an important factor in the onset of depression (Duman 2004). In fact, it has been demonstrated that, in rodents, IGF-1 can exert antidepressant-like effects after intracerebroventricular (ICV) or peripheral administration (Hoshaw et al. 2005; Duman et al. 2009; Basta-Kaim et al. 2014). Furthermore, IGF-1 could increase the basal level of serotonin in the ventral hippocampus 3 days after ICV administration, suggesting that IGF-1 could up-regulate serotonin levels in the brain (Hoshaw et al. 2008). On the other hand, chronic antidepressant treatment causes an increase in the hippocampal IGF-1 levels of rats and in the cerebrospinal fluid of humans (Khawaja et al. 2004). Based on the above-mentioned data, it may be suggested that there is an association of the IGF-1 system malfunction with the pathogenesis of depression.

To the best of our knowledge, there are no data concerning the regulation of the IGF-1 system in the OBs, the structures involved in the pathomechanism of depression. Therefore, the present study was designed to explore the mRNA expression and protein concentrations of IGF-1, as well as of IGF-1-binding protein levels (IGFBP-2, IGFBP4, IGFBP-3, and IGFBP-6), in an animal model of depression. Moreover, we focused on IGF-1 receptor expression and the amounts of total and phosphorylated (active) intracellular IGF-1R subunit in OBs in adult rats that were prenatally stressed. In a subsequent set of experiments, the impact of the chronic administration of antidepressant drugs belonging to various chemical groups (imipramine, fluoxetine, and tianeptine) on the prenatal stress-evoked changes in the brain IGF-1 network was determined. In the present study, the widely accepted animal model of depression, based on the prenatal stress procedure, was chosen (Rao et al. 1999; Morley-Fletcher et al. 2003, 2004; Szymańska et al. 2009a; Budziszewska et al. 2010). This model differs from other stress-related models because the animals are exposed to stressful conditions in the prenatal phase. Therefore, the changes induced by stress are long lasting.

\section{Materials and Methods}

\section{Animals}

Sprague-Dawley rats (200-250 g upon arrival) obtained from Charles-Rivers (Sulzfeld, Germany) were kept under standard conditions (at room temperature of $23{ }^{\circ} \mathrm{C}$, a 12/12 h light/dark cycle, and the lights on at 08:00 h), with food and water available ad libitum. Two weeks after 
arrival, vaginal smears were obtained daily from the female rats to determine the phase of the estrous cycle. On the proestrus day, the females were placed with males for $12 \mathrm{~h}$ and subsequently checked for the presence of sperm in vaginal smears. Pregnant females were randomly assigned to control and stress groups ( $n=10$ in each group). All of the experimental protocols were approved by the Committee for Laboratory Animal Welfare and Ethics of the Institute of Pharmacology, Polish Academy of Sciences, Cracow, and met the criteria of the International Council for Laboratory Animals and Guide for the Care and Use of Laboratory Animals. All efforts were made to minimize animal suffering and to reduce the number of animals used.

\section{Stress Procedure}

The prenatal stress procedure was performed as previously described (Morley-Fletcher et al. 2003, 2004; Basta-Kaim et al. 2014; Szewczyk et al. 2014). Briefly, pregnant females were subjected to three stress sessions daily, beginning on the 14th day of pregnancy and continuing until delivery. At $09.00,12.00$ and $17.00 \mathrm{~h}$, the rats were placed in plastic cylinders $(7 \times 12 \mathrm{~cm})$ and illuminated with strong light $(150 \mathrm{~W})$ for $45 \mathrm{~min}$. Control pregnant females were left undisturbed in their home cages. Only offspring from litters containing 10-12 pups with similar numbers of males and females were kept. Male offspring were selected from 21-day-old litters for the experiment. Twenty-four animals per group (control and prenatally stressed) were used for the experiments. They were housed in groups of four animals per cage (one or two animals from each litter) under standard conditions. At 3 months of age, the first behavioral verification was conducted.

\section{Forced Swim Test (FST)}

As before for verification of the animal model of depression, the forced swim test (FST, Porsolt test) was conducted according to the method previously described (Detke et al. 1995; Basta-Kaim et al. 2014). Briefly, the animals were individually subjected to two trials, during which they were forced to swim in a cylinder $(40 \mathrm{~cm}$ high and $18 \mathrm{~cm}$ in diameter) filled with water $\left(25^{\circ} \mathrm{C}\right)$ to a height of $30 \mathrm{~cm}$. There was a 24-h interval between the first and second trials. The first trial lasted $15 \mathrm{~min}$, and the second trial lasted 5 min. The total durations of immobility, mobility (swimming) and climbing were measured throughout the second trial (Porsolt et al. 1978; Detke et al. 1995).

\section{Antidepressant Drug Administration}

After the behavioral verification, the control and prenatally stressed offspring were randomly divided into 8 experimental groups (CONTROL + Veh, CONTROL + Imi, CONTROL + Flu, CONTROL + Tia, STRESS + Veh, STRESS + Imi, STRESS + Flu, and STRESS + Tia; 6 animals per group) and were treated for 14 days with antidepressant drugs. Imipramine (Imi; Sigma Aldrich, St. Louis, MO, USA), fluoxetine (Flu; Eli Lilly, Indianapolis, USA), or tianeptine (Tia; Tocris Bioscience, United Kingdom) were injected intraperitoneally, once daily between 09.00 and $10.00 \mathrm{~h}$ at a dose of $10 \mathrm{mg} / \mathrm{kg}$ in a volume of $2 \mathrm{ml} / \mathrm{kg}$ (diluted in $0.9 \%$ saline). The CONTROL + VEH and STRESS + VEH groups received $0.9 \%$ saline (Polpharma, Poland) in a volume of $2 \mathrm{ml} / \mathrm{kg}$ b.w. In the last 2 days of antidepressants treatment, the behavioral parameters in the forced swim test were measured (Fig. 1). The behavioral study was not blinded.

\section{Tissue Collection}

Twenty-four hours after the last injection of antidepressant drugs, the animals were sacrificed under non-stress conditions by rapid decapitation. The OBs were dissected onto ice-cold glass plates, and tissues were frozen on dry ice and stored at $-80{ }^{\circ} \mathrm{C}$ (for ELISA and western blot assays) or at $-20{ }^{\circ} \mathrm{C}$ prior to total RNA extraction.

\section{Sample Preparation}

The preparation of whole cell extracts was conducted according to the method described earlier (Budziszewska et al. 2010; Basta-Kaim et al. 2014). Briefly, the tissues were homogenized using an TissueLyzer II (Qiagen, Hilden Germany) in ice-cold radio-immunoprecipitation assay (RIPA) buffer, containing $100 \mu$ of Phosphatase Inhibitor Cocktail 1 and 2, $100 \mu$ of Protease Inhibitor Cocktail, $50 \mu \mathrm{l}$ of phenylmethanesulfonyl fluoride (PMSF), and sodium orthovanadate (OVS) for a total volume of $500 \mu \mathrm{l}$ (all reagents, Sigma Aldrich, St. Louis, MO, USA). The samples were shaken in an ice bath for $30 \mathrm{~min}$ and centrifuged at $14,000 \mathrm{rpm}$ for $20 \mathrm{~min}$ at $4{ }^{\circ} \mathrm{C}$. The supernatants were collected. The protein concentrations in the lysates were determined by the method of Lowry et al. (1951). The concentrations of cell extracts were standardized by dilution with lysis buffer to the lowest obtained protein concentration.

\section{Enzyme-Linked Immunosorbent Assay (ELISA)}

The concentrations of IGF-1 and IGF-binding proteins (IGFBP-2; IGFBP-3; IGFBP-4; IGFBP-6) in the OB supernatants were determined by ELISA, using commercially available kits (IGF-1, IGFBP-2: all Mediagnost, Reutlingen, Germany; IGFBP-4, IGFBP-6: all USCNK Life Science Inc., People's Republic of China; IGFBP-3: 


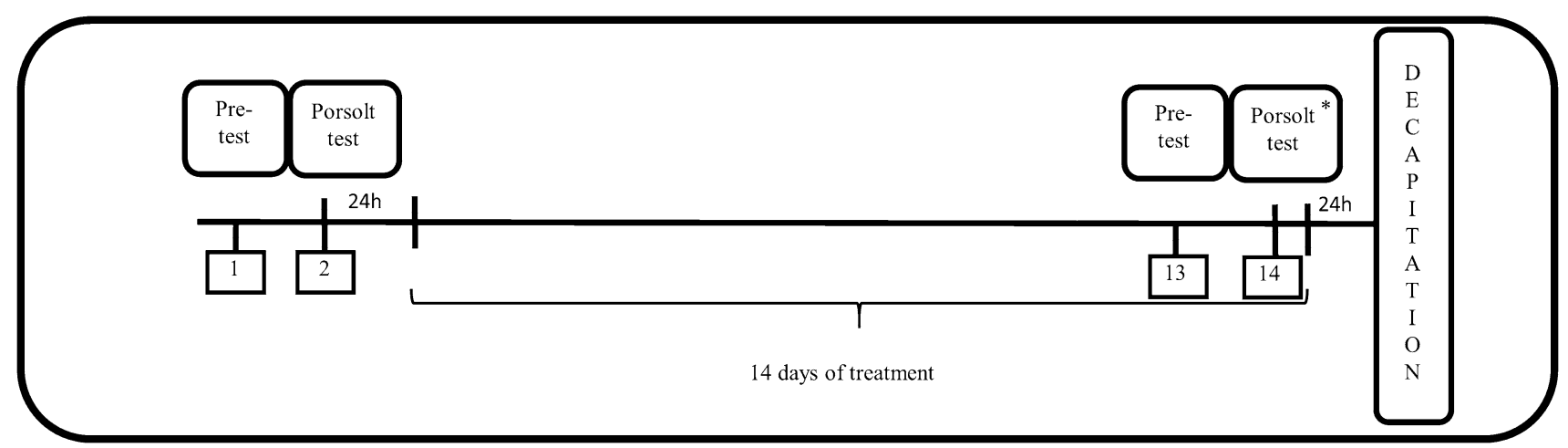

Fig. 1 Schematic diagram representing the schedule of the experiment. $* 2 \mathrm{~h}$ after pretest (13th day) or Porsolt (14th day) tests animals were treated with the antidepressants

DEMEDITEC Diagnostics GmbH, Kiel-Wellsee, Germany), according to the manufacturers' instructions. In case of IGF-1, total levels of IGF-1 (both free and bound) were determined.

Briefly, $50 \mu$ of the standards or samples were dispensed into 96 wells coated with rat IGF-1, IGFBP-2, IGFBP-3, IGFBP-4, or IGFBP-6 antibody and were incubated at room temperature. After extensive washing, $100 \mu 1$ of streptavidin-HRP was added, and the standards and samples were incubated for $30 \mathrm{~min} .3,3^{\prime}, 5,5^{\prime}$-tetramethylbenzidine (TMB) $(100 \mu \mathrm{l} /$ well $)$ was used as the chromogen for the colorimetric assay. The reaction was stopped after $10 \mathrm{~min}$ by adding $100 \mu \mathrm{l} /$ well of stop solution, the absorbance was determined using the Infinite 200 PRO Detector (TECAN, Mannedorf, Switzerland) system set to $450 \mathrm{~nm}$. The sensitivity of determination for each protein was as follows: IGF-1: $0.029 \mathrm{ng} / \mathrm{ml}$; IGFBP-2: $0.01 \mathrm{ng} / \mathrm{ml}$; IGFBP-3: $0.018 \mathrm{ng} / \mathrm{ml}$; IGFBP-4: $0.148 \mathrm{ng} /$ $\mathrm{ml}$; and IGFBP-6: $0.064 \mathrm{ng} / \mathrm{ml}$. For all of the study intraand inter-assays, the coefficients of variation were always $<7.5$ and $<10 \%$, respectively. Positive controls for each assay were provided by the manufacturers.

\section{Western Blot}

The Western blot method was described by Basta-Kaim et al. (2011). Briefly, the cell lysates were mixed with a buffer (100 mM Tris-HCl, $4 \%$ SDS, $20 \%$ glycerol, $10 \%$ 2-mercaptoethanol, $0.005 \%$ bromophenol blue, $\mathrm{pH}$ 6.8) and boiled for $3 \mathrm{~min}$ before loading onto the gel. The proteins were separated by SDS-PAGE (4\% stacking gel and $10 \%$ resolving gel) under constant voltage $(90 \mathrm{~V}$ in stacking gel and $120 \mathrm{~V}$ in resolving gel) and were transferred electrophoretically onto the PVDF membrane (Roche Diagnostic, Germany) at $70 \mathrm{~V}$ for $1 \mathrm{~h}$ and $20 \mathrm{~min}$. Membranes were washed twice with Tris-buffered saline (TBS), $\mathrm{pH} 7.5$, blocked in $5 \%$ nonfat milk for $1 \mathrm{~h}$ at room temperature, and incubated overnight at $4{ }^{\circ} \mathrm{C}$ with the appropriate primary antibody (anti-IGF-1 receptor beta (sc713, Santa Cruz Biotechnology, Texas, USA) or antiphospho-IGF-1 receptor antibody (ab85625, Abcam, USA) in $1 \%$ nonfat milk solution. The blots were washed twice with TBS containing $0.1 \%$ Tween-20 (TBST), twice with a $1 \%$ blocking solution in TBS and then were incubated with a horseradish peroxidase-linked secondary antibody (sc2030, Santa Cruz Biotechnology, Texas, USA) for $1 \mathrm{~h}$ at room temperature. Subsequently, the membranes were washed four times with large volumes of TBST, and the immunoblots were visualized with a chemiluminescence detection kit (Roche Diagnostic, Germany). $\beta$-actin (sc47778, Santa Cruz Biotechnology, Texas, USA) levels were used for normalization. The semi-quantitative analysis of band intensity was performed using the LAS-4000 image analyzer and Multi Gauge software (FujiFilm, Japan).

\section{Real-Time Polymerase Chain Reaction (RT-PCR)}

Freshly isolated OBs tissue samples were immediately placed in RNALater ${ }^{\circledR}$ solution (Applied Biosystems, USA) and stored at $-20{ }^{\circ} \mathrm{C}$ prior to total RNA extraction.

Total RNA was extracted using the RNeasy Mini Kit (Qiagen, Hilden, Germany) following the manufacturer's instructions. RNA concentrations were determined using a NanoDrop spectrophotometer (ND/1000 UV/Vis; Thermo Fisher NanoDrop, USA). Identical amounts of RNA $(1 \mu \mathrm{g})$ were reverse transcribed into cDNA using a commercial RT-PCR kit (Applied Biosystem, USA) according to the manufacturer's instructions.

Real-time PCR was performed using TaqMan probes and primers for genes coding the following: IGF-1 (Rn00710306_m1), IGF-1R (Rn00583837_m1), and FastStart Universal Probe Master (Rox) mix (Roche, Germany). Amplification was performed in a total volume of $20 \mu \mathrm{l}$ of mixture, containing $1 \times$ FastStart Universal Probe Master (Rox) mix (Roche, Germany), 50 ng of cDNA used as a PCR template, $900 \mathrm{nM}$ TaqMan forward and reverse 
primers, and a $250 \mathrm{nM}$ hydrolysis probe labeled with the fluorescent reporter dye FAM at the $5^{\prime}$-end, and quenching dye at the $3^{\prime}$-end. The thermal cycling conditions were as follows: $2 \mathrm{~min}$ at $50{ }^{\circ} \mathrm{C}$ and $10 \mathrm{~min}$ at $95{ }^{\circ} \mathrm{C}$ followed by 40 cycles at $95{ }^{\circ} \mathrm{C}$ for $15 \mathrm{~s}$ and $1 \mathrm{~min}$ at $60{ }^{\circ} \mathrm{C}$. Samples were run in duplicate. The threshold value $\left(C_{\mathrm{t}}\right)$ for each sample was set in the exponential phase of PCR, and the $\Delta \Delta C_{\mathrm{t}}$ method was used for data analysis (Applied BioSystems, United Kingdom). Beta-2-microglobulin (B2 M, Rn00560865_m1) was used as the reference gene.

\section{Statistical Analysis}

The outcomes of the behavioral studies are presented as the means \pm SEMs. The data obtained in the ELISA study are presented as weight units (ng) per milligram of protein \pm SEMs; those for RT-PCR as the average fold \pm SEM, and for Western blotting, the results are presented as percentage of the control \pm SEM. The normality of variable distribution and homogeneity of variances were checked by the Shapiro-Wilk test and Levene's test, respectively. The significance of the differences between the means was evaluated by one- or two-way analysis of variance (ANOVA), with Duncan's post hoc test if appropriate. A value of $p<0.05$ was considered statistically significant. All of the statistical analyses were performed using Statistica software, version 10.0 (Statsoft, Tulsa, USA).

\section{Results}

The Impact of Prenatal Stress on the Immobility, Swimming, and Climbing Time on the Forced Swim Test

To evaluate depression-like behavior in rats, we performed the forced swim test (Porsolt test). We confirmed that prenatal stress caused significantly prolonged immobility time (in seconds) (control-213.52 \pm 8.92 , stress$\left.263.45 \pm 7.33 ; F_{1,46}=288.92 ; p<0.05\right)$ and shortened swimming time (in seconds) (control-86.47 \pm 8.92 , stress-41.45 $\left.\pm 7.33 ; F_{1,46}=398.73 ; p<0.05\right)$, as well as climbing time (in seconds) (control-71.79 \pm 9.80 stress-39.14 $\left.\pm 6.51 ; F_{1,46}=224.37 ; p<0.05\right)$.

\section{The Impact of Antidepressant Drug Treatment on the Immobility, Swimming, and Climbing Time in the Forced Swim Test}

Next, to determine whether chronic imipramine, fluoxetine, or tianeptine administration affected the behavioral changes evoked by the prenatal stress, we assessed the Porsolt test again. As previously, we observed in prenatally stressed rats increase in the immobility $\left(F_{1,39}=90.40 ; p<0.05\right)$ and decrease in swimming $\left(F_{1,39}=57.34 ; p<0.05\right)$ and climbing $\left(F_{1,39}=17.12 ; p<0.05\right)$ times, which confirmed that the changes induced by stress were long lasting (Fig. 2a-c). Furthermore, we revealed a significant effect of drugs $\left(F_{3,39}=20.32 ; \quad p<0.05 ; \quad\right.$ Fig. $\left.2 \mathrm{a}\right)$ and the Stress $\times$ Drug Interaction $\left(F_{3,39}=5.48 ; p<0.05\right.$; Fig. 2a) on the immobility time. Post hoc comparisons revealed that imipramine $(p<0.05)$, fluoxetine $(p<0.05)$ and tianeptine $(p<0.05)$ shortened immobility time in prenatally stressed offspring. Also for swimming time, we observed a significant effect of drugs $\left(F_{3,39}=13.49 ; p<0.05\right.$; Fig. $\left.2 b\right)$ and the Stress $\times$ Drug Interaction $\left(F_{3,39}=3.76 ; p<0.05\right.$; Fig. 2b). Moreover, post hoc comparisons revealed that imipramine $(p<0.05)$, fluoxetine $(p<0.05)$, and tianeptine $(p<0.05)$ extended the swimming time in stressed offspring. In the case of the climbing time (Fig. 2c), we observed that only tianeptine $(p<0.05)$ prolonged the climbing time in prenatally stressed rats.

\section{The Impact of Prenatal Stress and Chronic Antidepressant Drug Administration on the mRNA Expression and Protein Levels of IGF-1 in the OBs}

Examination of the samples derived from the OBs revealed a significant down-regulation in the IGF-1 mRNA expression $\left(F_{1,34}=172.53 ; p<0.05\right)$ in prenatally stressed rats compared with the controls (unstressed animals) (Fig. 3a). Moreover, ANOVA showed a significant decrease in the IGF-1 protein concentrations in prenatally stressed offspring $\left(F_{1,32}=8.09 ; p<0.05\right)$ (Fig. 3b).

We also examined the effects of chronic antidepressant treatment on the mRNA expression and protein concentrations of IGF-1 in the OBs. As illustrated in Fig. 3, ANOVA showed a significant effect of drugs $\left(F_{3,34}=58.65 ; p<0.05\right)$ and the Stress $\times$ Drug Interaction on IGF-1 mRNA expression $\left(F_{3,34}=64.27\right.$; $p<0.05)$. We also noted a significant effect of drugs $\left(F_{3,32}=4.20 ; p<0.05\right)$ and the Stress $\times$ Drug interaction on IGF-1 protein levels $\left(F_{3,32}=5.76 ; p<0.05\right)$ (Fig. $\left.3 b\right)$. Post hoc comparisons revealed that chronic treatment with imipramine $(p<0.05)$, and tianeptine $(p<0.05)$ increased both the mRNA expression and protein concentrations of IGF-1, but fluoxetine $(p<0.05)$ only IGF-1 level in the OBs of prenatally stressed offspring.

\section{The Impact of Prenatal Stress and Chronic Antidepressant Drug Administration on the IGF-1 Binding Proteins Levels in OBs}

To determine whether prenatal stress affected other proteins in the IGF-1 family, we examined the levels of IGF-1binding proteins, i.e., IGFBP-2, -4, -3, and -6. 

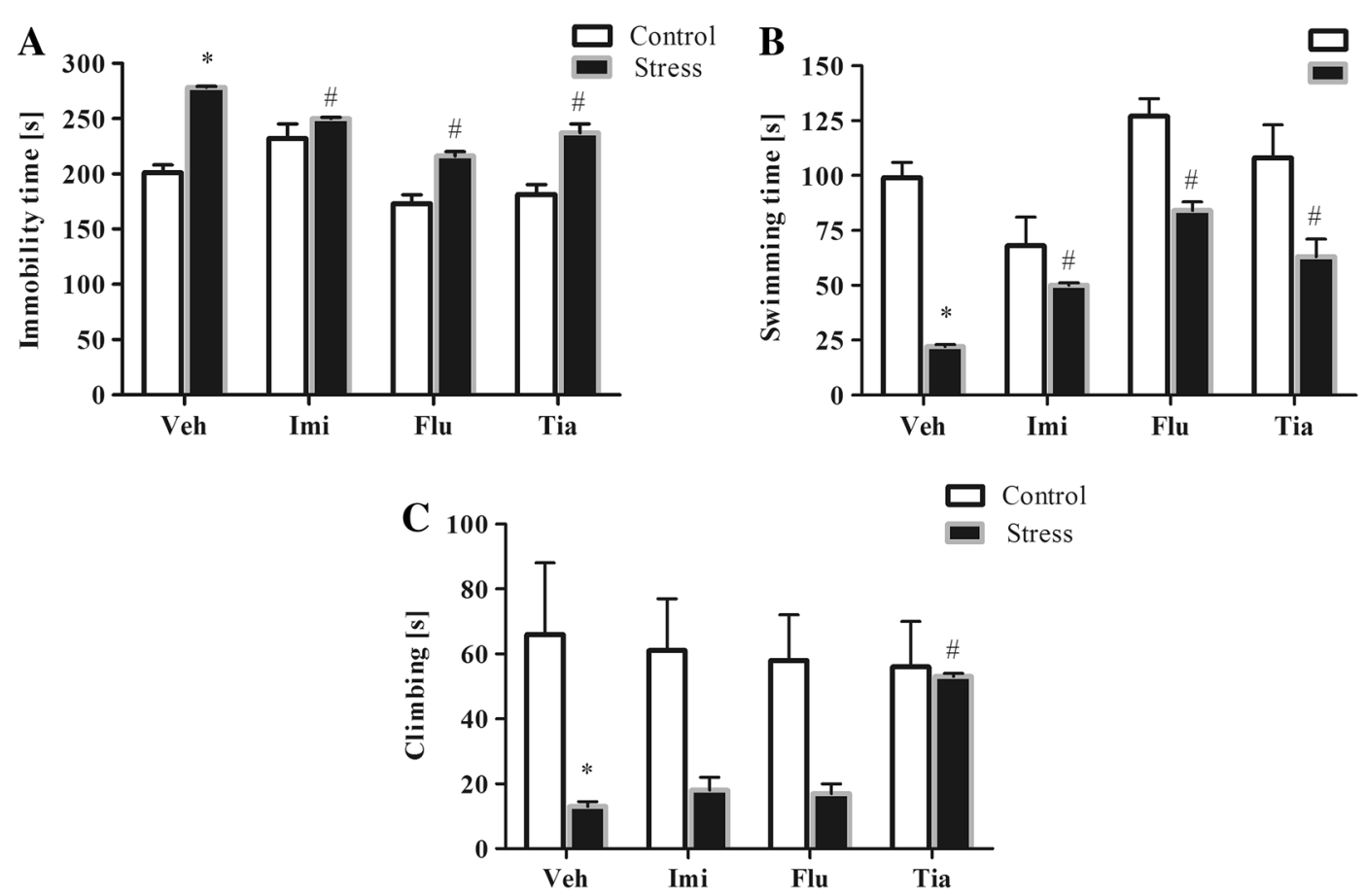

Fig. 2 The effects of prenatal stress and chronic antidepressant drug administration on the immobility (a), mobility (b), and climbing time (c) (in seconds) in the forced swim test. The data are presented as the means \pm SEMs, with $n=5-6$ for each group. $* p \leq 0.05$ versus

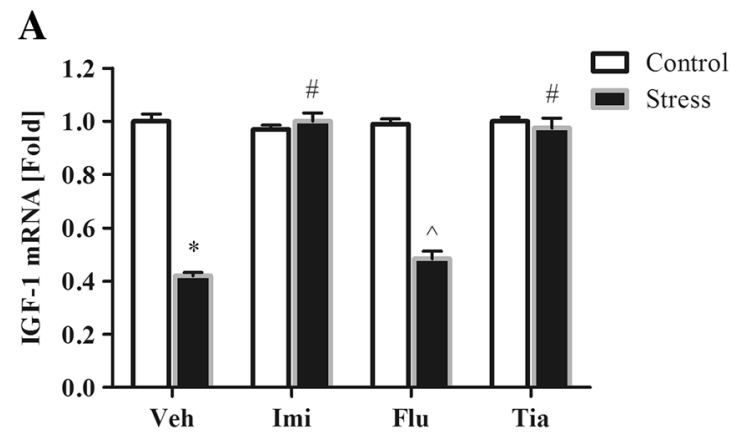

Fig. 3 The effects of prenatal stress and imipramine, fluoxetine, or tianeptine administration on IGF-1 mRNA expression (a) and IGF-1 levels (b) in the olfactory bulbs. mRNA expression is presented as the average fold \pm SEM and the protein level as $\mathrm{ng} / \mathrm{mg}$ of protein (mean \pm SEM). $n=5-6$ for each group, ${ }^{*} p \leq 0.05$ versus control

The results of ANOVA showed a significant decrease in IGFBP-2 (main binding protein expressed in the brain) level of prenatally stressed offspring $\left(F_{1,32}=58.04\right.$; $p<0.05)$. We also noted a significant effect of drugs $\left(F_{3,32}=141.74 ; p<0.05\right)$ and a significant Stress $\times$ Drug interaction $\left(F_{3,32}=118.86 ; p<0.05\right)$. For the first time, we demonstrated that chronic administration of fluoxetine $(p<0.05)$ and tianeptine $(p<0.05)$ statistically significantly increased IGFBP-2 levels in the OBs of prenatally stressed animals (Fig. 4a). control Veh group; ${ }^{\#} p \leq 0.05$ versus prenatally stressed Veh group. ANOVA (two-way), followed by Duncan's test. Veh vehicle, Imi imipramine, Flu fluoxetine, Tia tianeptine

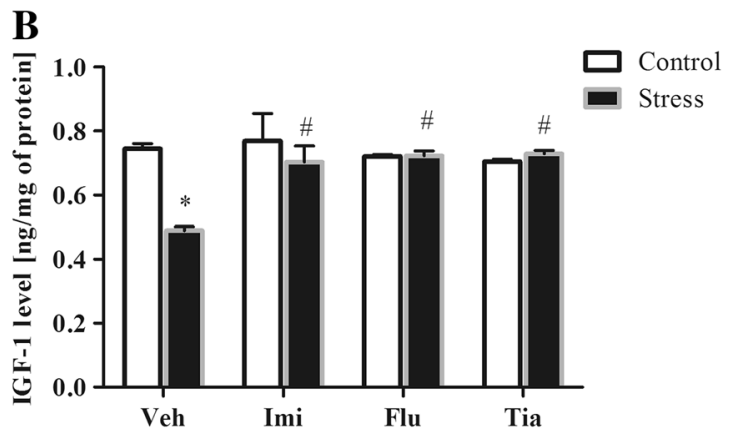

Veh group; ${ }^{\wedge} p \leq 0.05$ versus control Flu group; ${ }^{*} p \leq 0.05$ versus prenatally stressed Veh group. ANOVA (two-way), followed by Duncan's test. Veh vehicle, Imi imipramine, Flu fluoxetine, Tia tianeptine

In the next set of experiments, we found that the level of IGFBP-4, which operates in the brain mainly as an inhibitor of IGF-1 signaling, was significantly elevated in the OBs of prenatally stressed rats $\left(F_{1,32}=31.00 ; p<0.05\right)$. Moreover, ANOVA showed a significant effect of drugs $\left(F_{3,32}=21.42 ; p<0.005\right)$ and a Stress $\times$ Drug interaction $\left(F_{3,32}=18.95 ; p<0.05\right)$. Post hoc comparisons revealed that all of the antidepressants-fluoxetine $(p<0.05)$, tianeptine $(p<0.05)$, and imipramine $(p<0.05)$-decreased the IGFBP-4 level in prenatally stressed offspring (Fig. 4c). 
Furthermore, our study demonstrated that the prenatal stress procedure reduced the IGFBP-3 concentration $\left(F_{1,32}=72.14 ; p<0.05\right)$. Among the antidepressants tested, post hoc comparison showed that only tianeptine $(p<0.05)$ increased IGFBP-3 levels in the OBs of prenatally stressed offspring (Fig. 4b). In contrast, no changes in IGFBP-6 levels were observed after the prenatal stress procedure $\left(F_{1,32}=1.12 ; \mathrm{ns}\right)$ and antidepressant drug administration $\left(F_{3,32}=3.24\right.$; ns) (Fig. $\left.4 d\right)$.

\section{The Impact of Prenatal Stress and Chronic Antidepressant Drug Administration on the mRNA Expression and Phosphorylation Level of IGF-1 Receptor in OBs}

The results of RT-PCR analysis revealed that IGF-1R gene expression was statistically significantly decreased $\left(F_{1,34}=81.93 ; p<0.05\right)$ in animals subjected to prenatal stress (Fig. 5a). Next, ANOVA showed a significant Drug $\times$ Stress interaction regarding IGF-1R mRNA expression $\left(F_{3,34}=13.67 ; p<0.05\right)$. Post hoc comparisons revealed that chronic administration of fluoxetine $(p<0.05)$ and tianeptine $(p<0.05)$ increased the IGF-1R mRNA expression in prenatally stressed offspring. On the other hand, imipramine had no effect on the IGF-1R mRNA expression (Fig. 5a).
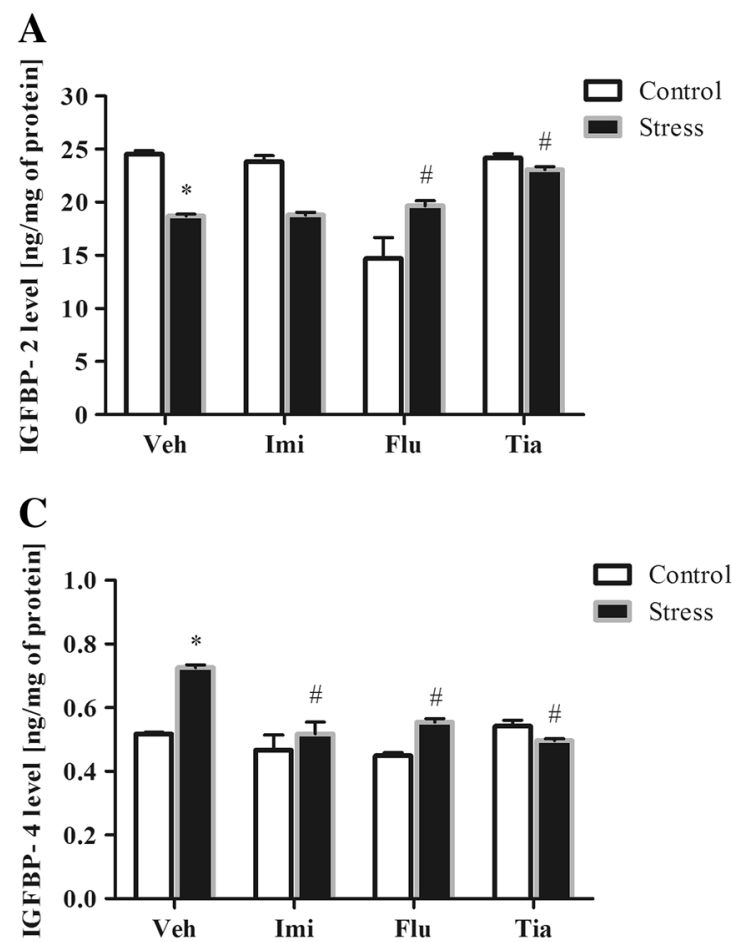

Fig. 4 The effects of prenatal stress and imipramine, fluoxetine, or tianeptine administration on the levels of IGFBP-2 (a), IGFBP-3 (b), IGFBP-4 (c), and IGFBP-6 (d) in the olfactory bulbs. The results are presented as ng per $\mathrm{mg}$ of protein (mean $\pm \mathrm{SEM}$ ). $n=5-6$ for each
Moreover, prenatal stress significantly decreased the ratio of the phosphorylated form of the $\beta$ subunit to the total IGF-1 R $\beta$ subunit $\left(F_{1,34}=4.41 ; p<0.05\right)$. We also noted significant effects of drug $\left(F_{3,34}=18.89 ; p<0.05\right)$ and the Stress $\times$ Drug Interaction $\left(F_{3,34}=15.17\right.$; $p<0.05$ ) (Fig. 5b). Post hoc comparisons revealed that fluoxetine $(p<0.05)$, tianeptine $(p<0.05)$, and imipramine $(p<0.05)$ normalized the IGF-1 receptor phosphorylation in stressed animals (Fig. 5b).

\section{Discussion}

Present studies confirmed our observations indicating behavioral disturbances in the offspring of rat dams that were stressed during pregnancy (Morley-Fletcher et al. 2003, 2004; Szymanska et al. 2009a, b; Budziszewska et al. 2010; Basta-Kaim et al. 2014). Prenatally stressed rats exhibit not only an increase in immobility time but also decreases in swimming and climbing behaviors, as shown in the modified Porsolt test. Moreover, the current study showed that imipramine, fluoxetine, and tianeptine eliminated stress-evoked changes in immobility and swimming behavior. Additionally, chronic tianeptine administration prolonged the climbing time in the modified Porsolt test in adult offspring. The effect of tianeptine may be due to its
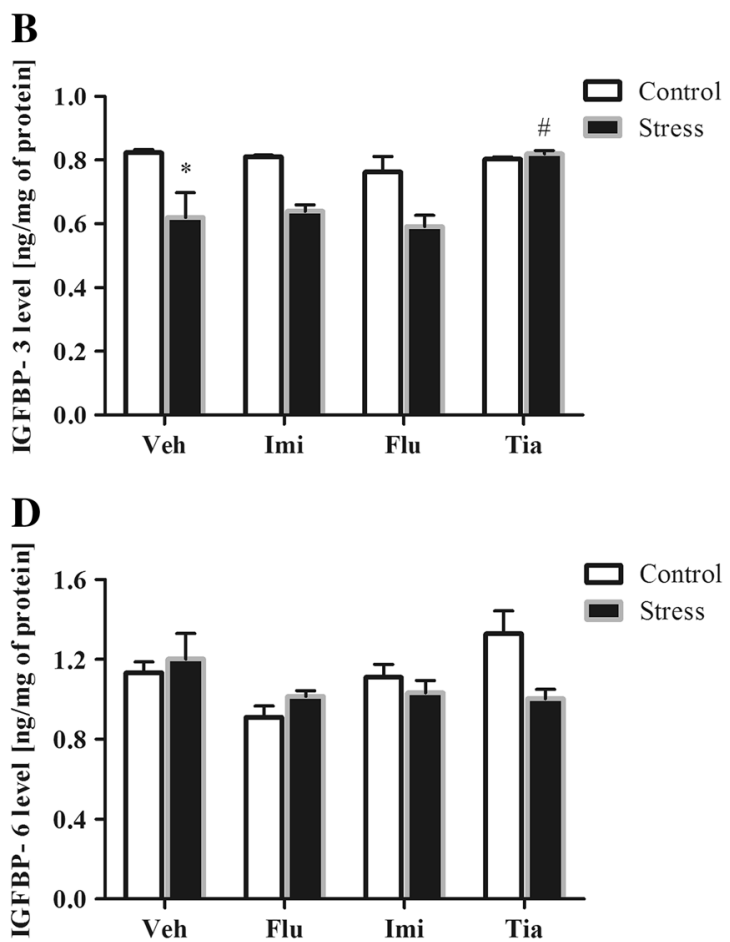

group, ${ }^{*} p \leq 0.05$ versus control Veh group; ${ }^{*} p \leq 0.05$ versus prenatally stressed Veh group. ANOVA (two-way) followed by Duncan's test. Veh vehicle, Imi imipramine, Flu fluoxetine, Tia tianeptine 
B
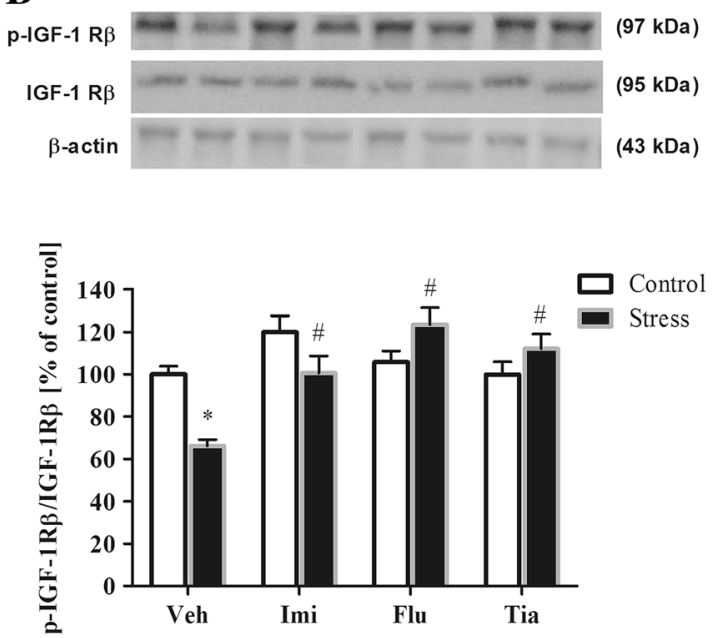

and presented as the $\%$ of control \pm SEM. $n=5-6$ for each group, $* p \leq 0.05$ versus control Veh group; ${ }^{*} p \leq 0.05$ versus prenatally stressed Veh group. ANOVA (two-way), followed by Duncan's test. $V e h$ vehicle, Imi imipramine, Flu fluoxetine, Tia tianeptine

and hippocampus. In fact, our previous results demonstrated that the prenatal stress procedure led to a decrease in the IGF-1 concentration in the frontal cortex and hippocampus of adult offspring (Basta-Kaim et al. 2014), which might suggest that the IGF-1 changes in the current model of depression occurred independent of the examined brain area. It is worth emphasizing that we also demonstrated that behavioral disturbances in prenatally stressed animals reversed the intracerebroventricular administration of IGF-1 (Basta-Kaim et al. 2014). Based on these observations, it could be suggested that, as observed in the present study, also diminished IGF-1 levels in OBs might be at least partially responsible for depressive-like behavior in stressed rats.

The mechanism responsible for brain IGF-1 regulation is fulfilled by IGF-binding proteins belonging to the IGF family. They act as carrier proteins for IGFs, regulate IGF1 transport, control its diffusion and efflux from the vascular space, increase its half-life, and modulate the interaction of IGF-1 with its receptors (Russo et al. 1997; Firth and Baxter 2002).

Particularly noteworthy is that we demonstrated changes in IGFBP levels in the OBs, such as decreases in IGFBP-2 and IGFBP-3, as well as an increase in IGFBP-4 concentrations. The OBs under normal conditions are rich in locally expressed components of the IGF system, including IGFBP-2, which is secreted by brain-resident neural and glial cells and regulates the transport and target of IGFs to the brain areas and prolongs the half-life of IGF-1 (Bezchlibnyk et al. 2006; Chesik et al. 2007). Data showed that IGF-I complexes with IGFBP-2 might promote

IGF-1 expression in other brain areas important to the pathogenesis of depression, especially the frontal cortex 
neurogenesis in adult animals and that this process was inhibited by the IGFBP-2 antibody (Brooker et al. 2000). Moreover, IGFBP-2 can bind to components of the extracellular matrix and concentrate IGF-1 near its receptor, thus enhancing IGF-1 activity (Bourner et al. 1992; Bezchlibnyk et al. 2006). Therefore, it might be postulated that the dampened IGFBP-2 levels observed in the OBs of adult male rats after the prenatal stress procedure might be responsible not only for the reduction in IGF-1 levels but also the interaction of IGF-1 with IGF-1 receptor.

Our previous data obtained from the hippocampus and frontal cortex showed decreases in the concentrations of IGFBP-2, as well as enhanced levels of IGFBP-4 in prenatally stressed animals (Basta-Kaim et al. 2014). In the present study in the OBs, we also demonstrated up-regulation of IGFBP-4, a protein involved in cell growth, development and common neuromodulation in the frontal cortex, hippocampus and OBs (Werther et al. 1998; Russo et al. 2005). Because most of the previous studies indicated an inhibitory role of IGFBP-4 on the IGF- 1 system both in vivo and in vitro (Mazerbourg et al. 2004; Praveen Kumar et al. 2014), it might be suggested that IGFBP-4 upregulation in prenatally stressed rats might be responsible for diminished IGF-1 levels and the suppression of IGF-1 signaling.

The second main finding of our study was the observation that chronic imipramine, fluoxetine, and tianeptine administration up-regulated IGF-1 expression in the OBs of prenatally stressed rats. Moreover, antidepressants affected the malfunction of the IGFBP network; imipramine, fluoxetine, and tianeptine attenuated IGFBP-4 levels, while the IGFBP- 2 concentration was increased by fluoxetine and tianeptine. The outcomes of the present work showed that chronic antidepressant treatment restored the correct balance between IGFBP-2 and IGFBP-4, the levels of which determine proper biological action of IGF-1. Furthermore tianeptine treatment enhanced IGFBP-3 concentrations diminished by prenatal stress, which are important in the control of neurogenesis, gliogenesis, myelination, and synaptic formation (Ajo et al. 2003; Bunn et al. 2005; Kalluri and Dempsey 2011). In contrast, none of the antidepressant drugs affected the IGFBP-6 level.

It should be emphasized that there are no data concerning the impact of chronic antidepressant administration on the IGF-1 network in the OB. However, in some brain areas, antidepressants, especially fluoxetine, potentiate IGF-I expression (Khawaja et al. 2004) and increase its concentrations in the cerebrospinal fluid (Schilling et al. 2011). Although there is little information about the involvement of antidepressant drugs on IGF-1 activity, it has been found that fluoxetine administration affects the IGF-1 system in the cortex and hippocampus differently. After chronic fluoxetine treatment, the hippocampus displayed IGF-1 down-regulation, while the frontal cortex IGF-1 level tended to be up-regulated (Grunbaum-Novak et al. 2008). Moreover, a specific antibody against the IGFI receptor or an antiserum raised against IGF-I reversed this antidepressant-evoked potentiation (Paslakis et al. 2012). Thus, the studies conducted so far have indicated that the effect of antidepressant drugs on IGF-1 depends not only on the treatment duration and brain structure but also; they may also differently affect IGF-1 mRNA expression and concentration, like in our studies fluoxetine did. Unequivocal determination of mechanisms of those discrepancies requires further studies.

Our present results indicated that chronic fluoxetine treatment not only up-regulated IGF-1 levels but also enhanced the IGF-1 beta-subunit receptor phosphorylation, which was diminished in the OBs of prenatally stressed offspring. The same effect after chronic tianeptine and imipramine treatment has been observed.

The IGF-1 receptor is expressed in both the $\mathrm{OB}$ and olfactory epithelium; therefore, some data have suggested an important role in the bulbo-epithelial interactions of the IGF-1 family in the olfactory system (Matsui et al. 2014). Because antidepressant treatment promotes neuronal plasticity, including neurogenesis and neuronal maturation, an increase in IGF-1 receptor phosphorylation in the OB, particularly induced by fluoxetine and tianeptine, might be relevant to the antidepressant action. But it is also possible that chronic treatment with antidepressants by normalization of both the immune system and HPA axis activity (Pariante and Miller 2001; Pariante et al. 2004) increases IGF-1 expression and IGF-1 receptor phosphorylation (Castren 2004).

Because our study demonstrated IGF-1 system malfunction in prenatally stressed rats, it could be postulated that biological IGF-1 properties in the OB, such as myelination of neuronal axons, formation of synaptic networks, synaptic plasticity, survival, longevity of cells in developing and adult neurons, and cognitive functions, are disturbed. Moreover, because the data demonstrated that IGF-1 plays an important role during neurogenesis, including its involvement in regulating radial neuronal migration and positioning within the $\mathrm{OB}$, as well as in the incorporation of newly formed neurons from the subventricular zone (SVZ) into the OB, the prenatal stress procedure might disrupt their course (Hurtado-Chong et al. 2009; Whitman and Greer 2009). Finally, because the OBs have connections with other brain regions, mainly the olfactory-limbic circuit, disturbances in the olfactory IGF-1 system of adult rats might affect reorganization processes in limbic and cortical areas, and these disturbances appear to be responsible for behavioral abnormalities (Zueger et al. 2005; Machado et al. 2012). Thus, the beneficial effect of antidepressant drugs on behavioral disturbances 
might result from their impact on the IGF-1 network, not only in the OBs but also in the limbic system remaining dependent of them.

\section{Conclusions}

In conclusion, our study provided the first evidence that stress during pregnancy led not only to behavioral disturbances but also to malfunction of the IGF-1 network in OBs. Furthermore, it was found that the beneficial effects of chronic antidepressant drug treatment resulted not only from the potentiation of $\mathrm{IGF}-1$ receptor expression and phosphorylation but also from the normalization of the IGF-1 level, probably via its impact on the IGF-1 binding protein network in adult male rats. It can be suggested that the IGFBP system might be a potential target for antidepressant drug treatment, but these hypotheses require further investigations.

Acknowledgments The authors thank Barbara Korzeniak for her skillful technical assistance.

Funding This research was supported by the Grant POIG.01.01.0212-004/09-00 part 2.4, "Depression Mechanisms Therapy," financed by the European Regional Development Fund and by the statutory funds of the Institute of Pharmacology of the Polish Academy of Sciences. Joanna Ślusarczyk and Ewa Trojan are scholarships recipients from the KNOW, sponsored by the Ministry of Science and Higher Education, Poland.

\section{Compliance with Ethical Standards}

Conflict of interest All authors declare no actual or potential conflicts of interest.

Open Access This article is distributed under the terms of the Creative Commons Attribution 4.0 International License (http://crea tivecommons.org/licenses/by/4.0/), which permits unrestricted use, distribution, and reproduction in any medium, provided you give appropriate credit to the original author(s) and the source, provide a link to the Creative Commons license, and indicate if changes were made.

\section{References}

Ajo R, Cacicedo L, Navarro C, Sánchez-Franco F (2003) Growth hormone action on proliferation and differentiation of cerebral cortical cells from fetal rat. Endocrinology 144(3):1086-1097

Annuziata M, Granata R, Ghigo E (2011) The IGF system. Acta Diabetol 48(1):1-9

Ashpole NM, Sanders JE, Hodges EL, Yan H, Sonntag WE (2015) Growth hormone, insulin-like growth factor-1 and the aging brain. Exp Gerontol 68:76-81

Basta-Kaim A, Budziszewska B, Leśkiewicz M, Fijał K, Regulska M, Kubera M, Wędzony K, Lasoń W (2011) Hyperactivity of the hypothalamus-pituitary-adrenal axis in lipopolysaccharideinduced neurodevelopmental model of schizophrenia in rats: effects of antipsychotic drugs. Eur J Pharmacol 650(2-3): 586-595

Basta-Kaim A, Szczesny E, Glombik K, Stachowicz K, Slusarczyk J, Nalepa I, Zelek-Molik A, Rafa-Zablocka K, Budziszewska B, Kubera M, Leskiewicz M, Lason W (2014) Prenatal stress affects insulin-like growth factor-1 (IGF-1) level and IGF-1 receptor phosphorylation in the brain of adult rats. Eur Neuropsychopharmacol 24(9):1546-1556

Bezchlibnyk YB, Wang JF, Shao L, Young LT (2006) Insulin-like growth factor binding protein-2 expression is decreased by lithium. NeuroReport 17(9):897-901

Bondy CA (1991) Transient IGF-I gene expression during the maturation of functionally related central projection neurons. J Neurosci 11:3442-3455

Bourner MJ, Busby WH Jr, Siegel NR, Krivi GG, McCusker RH, Clemmons DR (1992) Cloning and sequence determination of bovine insulin-like growth factor binding protein-2 (IGFBP-2): comparison of its structural and functional properties with IGFBP-1. J Cell Biochem 48(2):215-226

Branchi I, Francia N, Alleva E (2004) Epigenetic control of neurobehavioural plasticity: the role of neurotrophins. Behav Pharmacol 15:353-362

Bredt D, Furey ML, Chen G, Lovenberg T, Drevets WC, Manji HK (2015) Translating depression biomarkers for improved targeted therapies. Neurosci Biobehav Rev. doi:10.1016/j.neubiorev. 2015.09.013

Brooker GJ, Kalloniatis M, Russo VC, Murphy M, Werther GA, Bartlett PF (2000) Endogenous IGF-1 regulates the neuronal differentiation of adult stem cells. J Neurosci Res 59:332-341

Budziszewska B, Szymanska M, Leskiewicz M, Basta-Kaim A, Jaworska-Feil L, Kubera M, Jantas D, Lason W (2010) The decrease in JNK- and p38-MAP kinase activity is accompanied by the enhancement of PP2A phosphate level in the brain of prenatally stressed rats. J Physiol Pharmacol 61(2):207-215

Bunn RC, King WD, Winkler MK, Fowlkes JL (2005) Early developmental changes in IGF-I, IGF-II, IGF binding protein1 , and IGF binding protein- 3 concentration in the cerebrospinal fluid of children. Pediatr Res 58(1):89-93

Castren E (2004) Neurotrophic effects of antidepressant drugs. Curr Opin Pharmacol 4:58-64

Chesik D, De Keyser J, Wilczak N (2007) Insulin-like growth factor binding protein-2 as a regulator of IGF actions in CNS: implications in multiple sclerosis. Cytokine Growth Factor Rev 18(3-4):267-278

de Pablo F, de la Rosa EJ (1995) The developing CNS: a scenario for the action of proinsulin, insulin and insulin-like growth factors. Trends Neurosci 18(3):143-150

Detke MJ, Rickels M, Lucki I (1995) Active behaviors in the rat forced swimming test differentially produced by serotonergic and noradrenergic antidepressants. Psychopharmacol 121:66-72

Duman R (2004) Role of neurotrophic factors in the etiology and treatment of mood disorders. Neuromolecular Med 5(1):11-25

Duman CH, Schlesinger L, Terwilliger R, Russell DS, Newton SS, Duman RS (2009) Peripheral insulin-like growth factor-I produces antidepressant-like behavior and contributes to the effect of exercise. Behav Brain Res 198(2):366-371

Firth SM, Baxter RC (2002) Cellular actions of the insulin-like growth factor binding proteins. Endocr Rev 23:824-854

Freitas AE, Machado DG, Budni J, Neis VB, Balen GO, Lopes MW, de Souza LF, Dafre AL, Leal RB, Rodrigues AL (2013) Fluoxetine modulates hippocampal cell signaling pathways implicated in neuroplasticity in olfactory bulbectomized mice. Behav Brain Res 237:176-184

Grunbaum-Novak N, Taler M, Gil-Ad I, Weizman A, Cohen H, Weizman R (2008) Relationship between antidepressants and 
IGF-1 system in the brain: possible role in cognition. Eur Neuropsychopharmacol 18:431-438

Han VK, Matsell DG, Delhanty PJ, Hill DJ, Shimasaki S, Nygard K (1996) IGF-binding protein mRNAs in the human fetus: tissue and cellular distribution of developmental expression. Horm Res 45:160-166

Hoshaw BA, Malberg JE, Lucki I (2005) Central administration of IGF-I and BDNF leads to long-lasting antidepressant-like activity. Brain Res 1037(1-2):204-208

Hoshaw BA, Hill TI, Crowley JJ, Malberg JE, Khawaja X, Rosenzweig- Lipson S, Schechter LE, Lucki I (2008) Antidepressant-like behavioral effects of IGF-1 produced by enhanced serotonin transmission. Eur J Pharmacol 594(1-3):109-116

Hurtado-Chong A, Yusta-Boyo MJ, Vergaño-Vera E, Bulfone A, de Pablo F, Vicario-Abejón C (2009) IGF-I promotes neuronal migration and positioning in the olfactory bulb and the exit of neuroblasts from the subventricular zone. Eur $\mathrm{J}$ Neurosci 30(5):742-755

Kalluri HS, Dempsey RJ (2011) IGFBP-3 inhibits the proliferation of neural progenitor cells. Neurochem Res 36(3):406-411

Kelly JP, Wrynn AS, Leonard BE (1997) The olfactory bulbectomized rat as a model of depression: an update. Pharmacol Ther 74:299-316

Khawaja X, Xu J, Liang JJ, Barrett JE (2004) Proteomic analysis of protein changes developing in rat hippocampus after chronic antidepressant treatment: implications for depressive disorders and future therapies. J Neurosci Res 75(4):451-460

Lowry OH, Rosebrough NJ, Farr AL, Randall RJ (1951) Protein measurement with the Folin phenol reagent. J Biol Chem 193(1):265-275

Machado DG, Cunha MP, Neis VB, Balen GO, Colla AR, Grando J, Brocardo PS, Bettio LE, Dalmarco JB, Rial D, Prediger RD, Pizzolatti MG, Rodrigues AL (2012) Rosmarinus officinalis L. hydroalcoholic extract, similar to fluoxetine, reverses depressivelike behavior without altering learning deficit in olfactory bulbectomized mice. J Ethnopharmacol 143(1):158-169

Matsui H, Noguchi T, Takakusaki K, Kashiwayanagi M (2014) Colocalization of TRPV2 and insulin-like growth factor-I receptor in olfactory neurons in adult and fetal mouse. Biol Pharm Bull 37(12): 1907-1912

Mazerbourg S, Callebaut I, Zapf J, Mohan S, Overgaard M, Monget P (2004) Update on IGFBP-4: regulation of IGFBP-4 levels and functions, in vitro and in vivo. Growth Horm IGF Res 4(2):71-84

McEwen BS, Chattarji S, Diamond DM, Jay TM, Reagan LP, Svenningsson P, Fuchs E (2010) The neurobiological properties of tianeptine (Stablon): from monoamine hypothesis to glutamatergic modulation. Mol Psychiatry 15(3):237-249

Morley-Fletcher S, Darnaudery M, Koehl M, Casolini P, Van Reeth O, Maccari S (2003) Prenatal stress in rats predicts immobility behavior in the forced swim test. Effects of a chronic treatment with tianeptine. Brain Res 989(2):246-251

Morley-Fletcher S, Darnaudéry M, Mocaer E, Froger N, Lanfumey L, Laviola G, Casolini P, Zuena AR, Marzano L, Hamon M, Maccari S (2004) Chronic treatment with imipramine reverses immobility behaviour, hippocampal corticosteroid receptors and cortical 5-HT(1A) receptor mRNA in prenatally stressed rats. Neuropharmacology 47(6):841-847

Ning Y, Schuller AG, Conover CA, Pintar JE (2008) Insulin-like growth factor (IGF) binding protein-4 is both a positive and negative regulator of IGF activity in vivo. Mol Endocrinol 22(5):1213-1225

Ocrant I (1991) Insulin-like growth factor binding proteins in the nervous system. Adv Exp Med Biol 293:471-482

Ocrant I (1993) Insulin-like growth factor binding proteins in nervous-tissue-derived cells. Ann N Y Acad Sci 692:44-50
Pariante CM, Miller AH (2001) Glucocorticoid receptors in major depression: relevance to pathophysiology and treatment. Biol Psychiatry 49(5):391-404

Pariante CM, Thomas SA, Lovestone S, Makoff A, Kerwin RW (2004) Do antidepressants regulate how cortisol affects the brain? Psychoneuroendocrinology 29(4):423-447

Paslakis G, Blum WF, Deuschle M (2012) Intranasal insulin-like growth factor I (IGF-I) as a plausible future treatment of depression. Med Hypotheses 79(2):222-225

Porsolt RD, Anton G, Blavet N, Jalfre M (1978) Behavioural despair in rats: a new model sensitive to antidepressant treatments. Eur J Pharmacol 47:379-391

Praveen Kumar VR, Sehgal P, Thota B, Patil S, Santosh V, Kondaiah $P$ (2014) Insulin like growth factor binding protein 4 promotes GBM progression and regulates key factors involved in EMT and invasion. J Neurooncol 116(3):455-464

Rao U, McGinty DJ, Shinde A, McCracen JT, Poland RE (1999) Prenatal stress is associated with depression-related electroencephalographic sleep changes in adult males rats: a preliminary report. Prog Neuropsychopharmacol Biol Psychiatry 23:929-939

Russo VC, Bach LA, Fosang AJ, Baker NL, Werther GA (1997) Insulin-like growth factor binding protein-2 binds to cell surface proteoglycans in the rat brain olfactory bulb. Endocrinology 138:4858-4867

Russo VC, Gluckman PD, Feldman EL, Werther GA (2005) The insulin-like growth factor system and its pleiotropic functions in brain. Endocr Rev 6(7):916-943

Schilling C, Blum WF, Heuser I, Paslakis G, Deuschle M (2011) Treatment with antidepressants increases insulin-like growth factor-I in cerebrospinal fluid. J Clin Psychopharmacol 31:390-392

Song C, Leonard BE (2005) The olfactory bulbectomised rat as a model of depression. Neurosci Biobehav Rev 29:627-647

Sowa J, Bobula B, Glombik K, Slusarczyk J, Basta-Kaim A, Hess G (2015) Prenatal stress enhances excitatory synaptic transmission and impairs long-term potentiation in the frontal cortex of adult offspring rats. PLoS One 10(3):e0119407

Szewczyk B, Kotarska K, Daigle M, Misztak P, Sowa-Kucma M, Rafalo A, Curzytek K, Kubera M, Basta-Kaim A, Nowak G, Albert PR (2014) Stress-induced alterations in 5-HT1A receptor transcriptional modulators NUDR and Freud-1. Int J Neuropsychopharmacol 17(11):1763-1775

Szymańska M, Budziszewska B, Jaworska-Feil L, Basta-Kaim A, Kubera M, Leśkiewicz M, Regulska M, Lasoń W (2009a) The effect of antidepressant drugs on the HPA axis activity, glucocorticoid receptor level and FKBP51 concentration in prenatally stressed rats. Psychoneuroendocrinology 34(6):822-832

Szymańska M, Suska A, Budziszewska B, Jaworska-Feil L, BastaKaim A, Leśkiewicz M, Kubera M, Gergont A, Kroczka S, Kaciński M, Lasoń W (2009b) Prenatal stress decreases glycogen synthase kinase-3 phosphorylation in the rat frontal cortex. Pharmacol Rep 61(4):612-620

Uzbekov MG (2009) Antidepressant action of tianeptine is connected with acceleration of serotonin turnover in the synapse: a hypothesis. Neuropsychopharmacol Hung 11(2):83-87

Werther GA, Russo V, Baker N, Butler G (1998) The role of the insulin-like growth factor system in the developing brain. Horm Res 49(1):37-40

Whitman MC, Greer CA (2009) Adult neurogenesis and the olfactory system. Prog Neurobiol 89(2):162-175

Zueger M, Urani A, Chourbaji S, Zacher C, Roche M, Harkin A, Gass $\mathrm{P}$ (2005) Olfactory bulbectomy in mice induces alterations in exploratory behavior. Neurosci Lett 374(2):142-146 